\section{O MAL-ESTAR NA PSICANÁLISE}

Lacan e Deleuze, de Mário Bruno. Rio de Janeiro: Forense, 2004, 236p.

\section{Evando Nascimento}

Professor na Universidade Federal de Juiz de Fora e autor, entre outros, de Derrida e a literatura (EdUFF).

Houve um tempo, entre os anos 1960 e 70, em que a psicanálise gozava de alto prestígio no âmbito das ciências humanas e domínios conexos. Isso se deveu em grande parte ao privilégio dado pelo estruturalismo no que se refere à linguagem e à contribuição correlata de Jacques Lacan aos estudos empreendidos na época.

Na literatura, particularmente, emergiu todo um campo de pesquisas que, no melhor dos casos, não colocava o texto no divã (situação absurda porque não se trata nunca de uma subjetividade plena, mas de uma elaboração criativa), porém investigava-se o modo como o discurso psicanalítico poderia esclarecer certas estruturas ficcionais e, em contrapartida, como a própria literatura poderia contribuir para melhor compreensão das formações do inconsciente.
Hoje, esse diálogo persiste com bem menor intensidade, certamente pelo declínio da influência da psicanálise de modo geral. No campo da clínica, a vaga norte-americana de rejeição da terapia psicanalítica, em proveito do recurso a medicamentos tão rentáveis quanto de duvidosa eficácia no longo prazo, tem reforçado esse desprestígio generalizado da teoria e da prática psicanalíticas. Isso a despeito do valor inequívoco de algumas das descobertas de Freud e dos múltiplos desdobramentos de seu trabalho ao longo do século XX.

Um dos grandes méritos do livro Lacan \& Deleuze, de Mário Bruno, doutor em teoria psicanalítica pela UFRJ e professor de literatura na Uerj, é o de relançar alguns dos debates importantes relativos à teoria psicanalítica (em diálogo com a filosofia) e de dirimir alguns dos equívocos mais persistentes, sobretudo em torno da escrita de Jacques Lacan. Tal confusão ocorre em função do próprio estilo lacaniano, que despista e embaralha muitas de suas referências, estabelecendo cruzamentos inusitados entre, por exemplo, Kant e Sade. Dificulta mais ainda o entendimento dos labirínticos enunciados e parágrafos lacanianos o fato de serem transcrições de seminários não revisadas pelo autor. Deve-se sempre imaginar uma co-autoria nos casos em que o responsável teve que decidir pela colocação de uma vírgula ou pela interrupção de uma frase, com recurso ao ponto, além de acréscimos que suplementem a precariedade da fala improvisada.

A parte inicial do livro se encarrega de expor a importância de Alexandre Kojève (imigrante russo) sobre uma gama de pensadores franceses na primeira metade do século XX. A tão fetichizada noção lacaniana de "falta" encontra, assim, no hegelianismo de Kojève sua fundamen- 
tação inicial. É a essa falta que se vincula a negatividade fundante do desejo; nesse caso, a ausência é constitutiva - do mesmo modo como em Hegel o trabalho do negativo era indispensável à dialética do Espírito. "Assim, na raiz da ética está o desejo na sua mudez absoluta: a faute. A partir da morte do pai perverso (figura obscena e feroz) que existiu antes da história, cria-se um laço entre irmãos" (p.43).

A morte de Deus é interpretada não como em Nietzsche, segundo a impossibilidade de qualquer sujeito transcendental vir a ocupar a cena da existência, mas como reencenação da horda primitiva, descrita por Freud em Totem e tabu. Tal seria o mito mesmo da origem da Lei, mito este que para Lacan é indicativo da vinculação do desejo com a Lei. "Para Lacan, no além do princípio do prazer não há um Bem supremo, tal qual fora buscado na ética aristotélica; o que existe é a agressividade da pulsão de morte apresentando-se de modo cruel nos imperativos da consciência" (p.64).

No Seminário 7, elabora-se justamente a noção de Coisa, como retomada da Coisa em si kantiana, da referência a Das Ding do Projeto de Freud (de 1895) e à Coisa que comparece em Heidegger. Das Ding seria o Outro insubsumível à lógica do mesmo, porém ao ser interpretada hegelianamente em termos de negatividade, de uma falta radical, acaba correspondendo a uma das formas históricas da ipseidade.

O problema do hegelianismo da noção de falta, a despeito de todos os avanços que propiciou no palco da reflexão ocidental, é que coloca Lacan ainda preso a uma tradição ontológica que afirma a positividade do ser com o recurso ao trabalho do negativo, como momento indispensável da superação dialética. A psicanálise lacaniana se vê relançada desse modo no recinto da tradição metafísica, correndo-se em última instância o risco de fazer do inconsciente simplesmente um momento da evolução do Espírito ou, pior, da consciência racional. Evidentemente, tal não ocorre no trabalho laborioso de Lacan, mas o comprometimento com uma tradição filosófica em relação à qual Freud fez absoluta questão de romper (a que opunha peremptoriamente o inconsciente à consciência reflexiva) se torna uma armadilha, na medida que se reintroduzem, num discurso em aparência revolucionário, categorias relativas a um horizonte de pensamento que sobretudo Nietzsche conseguiu abalar e tornar permanentemente problemático.

A segunda parte do livro vai contrapor essa ética trágica da falta, como constituinte fundamental do desejo e por conseqüeência do sujeito, um pensamento afirmativo, por assim dizer tragicamente dionisíaco, que se depreende de Diferença e repetição, de Gilles Deleuze. Com Deleuze, não apenas a noção de falta se vê deslocada, mas a própria essencialidade do sujeito é substituída por categorias como repetição, diferença e devir. "Deleuze, em vez de nos remeter à limitação imposta por uma ontologia do negativo, no qual das Ding é somente o inominável, o irrepresentável, apresenta um mundo inteiro de diferenças no qual o sensível encontra o seu ser. É um empirismo que nos conduz ao trágico da repetição no eterno retorno" (p.141).

Nesse sentido, haveria dois modos de pensar o para-além-do-princípio-doprazer freudiano. O primeiro, de acordo com o Seminário 7 de Lacan, consistiria em sobredeterminar tanto o prazer quanto o próprio desejo, numa negatividade que esvazia por antecipação (outros diriam, posterioridade...) qualquer possibilidade não propriamente de superação, mas de perda da pertinência do pensamento dialético. A autonomização da pulsão 
de morte reforçaria isso, que em última instância reconduz a uma metafísica do negativo.

O segundo modo de pensar o paraalém-do-princípio-do-prazer consiste em afirmar o devir como possibilidade do eterno retorno. Para Deleuze, leitor de Nietzsche, o retorno se faz por meio da alegria, trágica e por isso mesmo alegre, pois afirma a potência do que já aconteceu e que é selecionado para voltar. Em vez de uma ordem comandada pelo princípio do Uno, para Deleuze, subjaz às coisas o mundo pululante e alegremente caótico das diferenças, sem identidade última, nem mesmo uma que se desse através das vestes do negativo, segundo uma falta originária.

O princípio trágico em Deleuze é criativo e não remete, portanto, a uma vontade de destruição, nem mesmo como anulação postergada. Em pleno niilismo, como jogo nietzschiano das diferenças, prepondera o novo, o que se insurge a partir do confronto das forças. Como conclui o arguto ensaio de Mário Bruno:

“Não há dúvida de que Diferença e repetição apresenta uma interpretação radicalmente inversa do conceito de Todestriebe. O instinto de morte é um princípio transcendental disjuntivo: a irrupção do devir como disjunção imanente. Em vez de referir o instinto de morte à história, Deleuze o refere, nietzschianamente, ao devir que promove rupturas nas ligações operadas por Eros. Thánatos é o princípio disjuntivo que ameaça apagar o arquivo mnêmico.” (p.214)

Recebida em 25/01/2007.

Aprovada em 26/2/2007.

Evando Nascimento

evandobn@uol.com.br 